\title{
KOMPOSISI HASIL TANGKAPAN IKAN SIDAT MENGGUNAKAN BUBU DI SUNGAI TERUSAN, KABUPATEN KAUR, PROVINSI BENGKULU
}

\section{Catch Composition of Eel Fish using Trap in Terusan River, Kaur Regency, Bengkulu Province}

Oleh:

Ronny Irawan Wahju ${ }^{1 *}$, Am Azbas Taurusman ${ }^{1}$, Muji Nopriansah ${ }^{1}$

${ }^{1}$ 1) Departemen Pemanfaatan Sumberdaya Perikanan,FPIK-IPB, Bogor, Indonesia

${ }^{*}$ Korespondensi penulis: rwahyu06@gmail.com

\begin{abstract}
ABSTRAK
Sidat merupakan ikan yang unik karena dalam siklus hidupnya melakukan migrasi dari perairan tawar menuju ke perairan laut (katadromus) untuk memijah. Informasi mengenai perikanan jenis sidat serta komposisi hasil tangkapan menjadi penting dalam pemanfaatan sidat secara berkelanjutan. Penelitian ini bertujuan untuk mengidentifkasi jenis dan sebaran hasil tangkapan sidat, serta menganalisis komposisi dan keraragaman hasil tangkapan bubu sidat. Penelitian dilakukan dengan melakukan penangkapan menggunakan bubu di bagian hulu dan hilir sungai pada bulan JanuariFebruari 2020 di Sungai Terusan Kabupaten Kaur, Bengkulu. Hasil identifikasi ciri morfologi dan perbandingan nilai ano-dorsal terhadap tangkapan sidat yang diperoleh selama penelitian ditemukan tiga spesies sidat yakni $A$. bicolor bicolor dengan nilai perbandingan ano-dorsal sebesar 3,43-3,58 \% tertangkap pada bagian hilir sungai sedangkan $A$. marmorata (13,7-18,81 \%) dan $A$. nebulosa (9,21-9,36 $\%)$ tertangkap pada bagian hulu sungai. Komposisi spesies hasil tangkapan antara hulu dan hilir sangat berbeda dengan indeks keragaman (H') hasil tangkapan perairan hulu sungai sebesar 1,73 dan perairan hilir sungai 1,64.
\end{abstract}

Kata kunci: $A$. bicolor bicolor, $A$. marmorata, $A$. nebulosa, bubu, sidat

\begin{abstract}
Sidat is a unique fish because in its life cycle migrates from freshwater to seawater (katadromus) for spawning. Information on eel fisheries and catch composition is important for sustainable use of eel. The purposes of this study are to identify the species and distribution of eel catches, and to analyze the composition and diversity of the catches. The study was carried out from January to February 2020 in Terusan River, Kaur Regency, Bengkulu in the upstream and downstream areas of the riever. The results of the study shows that three species eels were identified namely A. bicolor bicolor with anodorsal ratio of (3.43-3.58\%) found in the downstream of the river, while A. marmorata (13.7-18.81\%) and A. nebulosa (9.21-9.36\%) found in the upper reaches of the river. The catch composition between upstream and downstream were significantly different based upon the diversity index ( $H^{\prime}$ ) of the catches in the upstream river of 1.73 and in the downstream of river waters was 1.64 .
\end{abstract}

Key words: A. bicolor bicolor, A. marmorata, A. nebulosa, eel, trap

\section{PENDAHULUAN}

Ikan sidat merupakan ikan yang unik karena dalam siklus hidupnya berada di dua tempat yakni perairan laut dan tawar (Syahril et al. 2016). Ikan sidat yang asal mulanya dari Anguillidae yang telah hidup sejak ribuan tahun lalu. Genus ini paling sedikit ada 17 spesies yang tersebar di seluruh dunia. Wilayah perairan Indonesia terdapat tujuh spesies atau sub-spesies, yaitu Anguilla celebesensis (Kaup 
1856), Anguilla interioris (Whitely 1938), Anguilla nebulosa nebulosa (McClelland 1844), Anguilla Marmorata (Quoy \& Gaimard 1824), Anguilla borneensis (Popta 1824), Anguilla bicolor bicolor (McClelland 1844) dan Anguilla bicolor pacifica (Schmidt 1928) (Tesch 1977 dalam Affandi 2005; Sugeha et al. 2008).

Ikan sidat merupakan jenis ikan yang mengalami hidup di dua habitat yaitu perairan laut selama masa stadia larva dan perairan umum daratan (payau dan tawar) selama masa stadia juvenil hingga dewasa. Sidat memijah di perairan laut dalam dan sebagian besar masa hidupnya dihabiskan di perairan tawar dan sungai. Sidat akan beruaya ke hulu sungai untuk berkembang dan hidup di habitat air tawar menjadi sidat dewasa hingga akhirnya kembali lagi ke laut untuk melakukan pemijahan (Fahmi 2015). Ikan sidat dewasa akan beruaya ke laut dalam untuk memijah (Arai et al. 2011; Tsukamoto et al. 2011; Fahmi 2015).

Kabupaten Kaur memiliki luas daratan mencapai $2.365 \mathrm{~km} 2$ dan secara geografis terletak antara $103^{\circ} 4^{\prime} 8,76^{\prime \prime}-103^{\circ} 46^{\prime} 50,12^{\prime \prime}$ BT dan $4^{\circ} 15^{\prime} 8,21^{\prime \prime}-4^{\circ} 55^{\prime} 27,77^{\prime \prime}$ LS yang menghadap langsung ke Samudera Hindia (Dwijayanto 2018). Kemiringan tofografi yang curam serta adanya aliran sungai yang deras membuat sungai menjadi salah satu habitat sidat (Hartono et al. 2015). Kabupaten Kaur memiliki aliran sungai yang terhitung cukup banyak yakni ada 13 sungai besar. Sungai-sungai mengalir langsung ke laut sehingga terdapat jenis ikan sidat yang mendiami perairan tersebut. Akan tetapi data dan informasi penangkapan sidat di Kabupaten Kaur masih terbatas.

Penangkapan ikan sidat untuk memenuhi kebutuhan sehari-hari sudah dilakukan oleh masyarakat Kabupaten Kaur. Namun data hasil tangkapan bubu sidat, seperti jenis dan komposisi serta keragamannya di Kabupaten Kaur masih belum tersedia. Data perikanan sidat sangat dibutuhkan sebagai informasi awal untuk jenis sidat yang tertangkap di daerah penangkapan sidat di Kabupaten Kaur. Kepastian jenis sidat berdasarkan analisis taksonominya sangat diperlukan untuk input penting pengelolaannya (Hakim et al. 2015). Sebaran daerah penangkapan sidat yang belum diketahui oleh nelayan, sehingga penangkapan masih dilakukan berdasarkan kebiasaan. Oleh karena itu, identifikasi secara morfologis berupa jenis, komposisi hasil tangkapan serta keragaman hasil tangkapan bubu di lokasi penangkapan perlu untuk dilakukan sebagai informasi dasar dalam pemanfaatan perikanan sidat di Kabupaten Kaur. Dengan demikian penelitian ini bertujuan untuk menganalisis komposisi jenis persebaran dan keragaman hasil tangkapan ikan dengan menggunakan bubu sidat di Sungai Terusan, Kaur, Bengkulu.

\section{METODE PENELITIAN}

Penelitian dilaksanakan pada bulan Januari-Februari 2020 di hulu dan hilir Sungai Terusan, Kecamatan Tetap, Kabupaten Kaur Bengkulu. Pemasangan bubu dilakukan pada posisi yang berbeda yaitu daerah hilir (perairan payau) dengan substrat lumpur, dan daerah hulu (perairan tawar) dengan substrat batuan, seperti yang disajikan pada Gambar 1. 


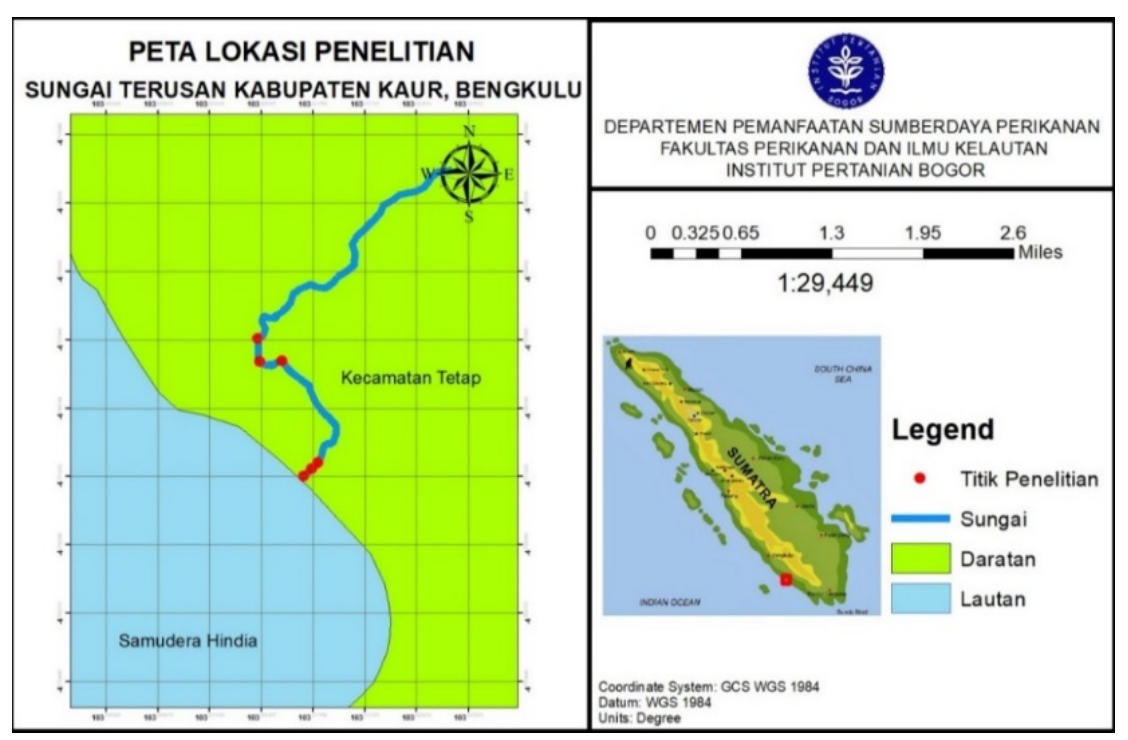

Gambar 1 Lokasi penelitian dan titik sampling

Metode penelitian dilakukan dengan experimental fishing, data yang dikumpulkan berupa hasil tangkapan sidat. Penangkapan ikan sidat dilakukan dengan menggunakan alat tangkap bubu yang dibuat dari anyaman bambu dengan ijeb ganda. Bubu yang digunakan dalam penangkapan sidat berbentuk silinder dengan ukuran panjang $80 \mathrm{~cm}$ dan diameter $17 \mathrm{~cm}$ bagian depan (mulut) dan $7 \mathrm{~cm}$ pada bagian belakang (Gambar 2).
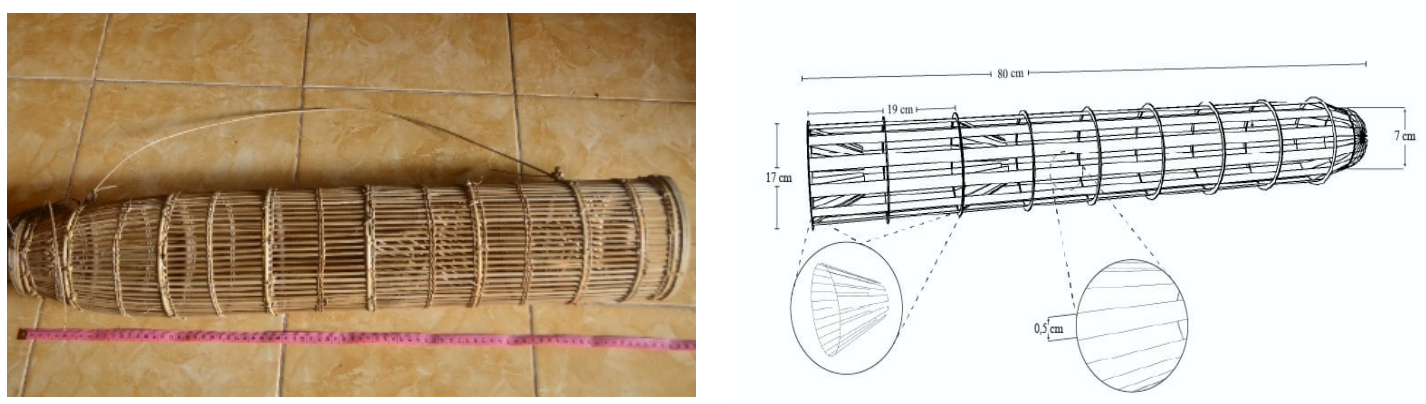

Gambar 2 Bubu yang digunakan dalam penelitian

Pemasangan bubu dilakukan di daerah hilir (perairan payau) dengan substrat lumpur dan daerah hulu (perairan tawar) dengan substrat batuan. Bubu dipasang dengan mulut dipasang melawan arah arus sungai dengan umpan yang digunakan ampas kelapa. Pemasangan bubu dilakukan pada enam stasiun yang berbeda dan masing-masing stasiun dilakukan pengulangan sebanyak sepuluh kali. Setiap melakukan penangkapan dilakukan juga pengukuran parameter lingkungan seperti kedalaman, suhu, kekeruhan, salinitas dan $\mathrm{pH}$ pada setiap stasiun. Pemasangan (setting) bubu dilakukan pada sore hari pukul 16.00-18.00 WIB dengan lama perendaman bubu (immersion time) sekitar 14 jam. Lokasi pemasangan bubu dapat dilihat pada Gambar 3. 


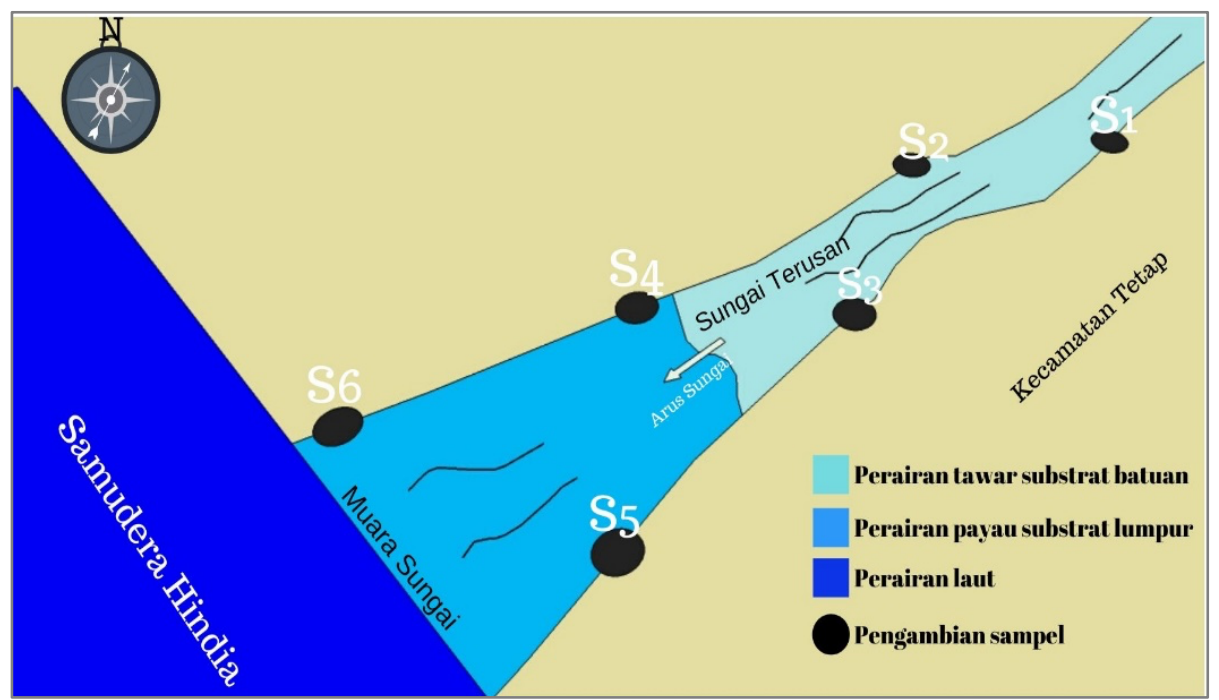

Gambar 3 Rancangan sampling pemasangan bubu sepanjang sungai Terusan mewakili perairan tawar dan payau

\section{Identifikasi jenis jenis sidat}

Untuk mengidentifikasi jenis sidat yang tertangkap menggunakan persamaan yang digunakan oleh Tabeta et al. (1976) dalam Hakim et al. (2015) dengan pendekatan uji perbandingan ano-dorsal (pengurangan antara panjang sirip punggung dikurangi panjang sirip dubur) dibagi dengan panjang total (TL) pada semua stadia ikan sidat (glass eel, muda, dan dewasa), seperti persamaan:

$$
A / D \%=\frac{A D}{T L} \times 100 \%
$$

Keterangan:

$\mathrm{AD}$ : ano-dorsal length

TL : total length

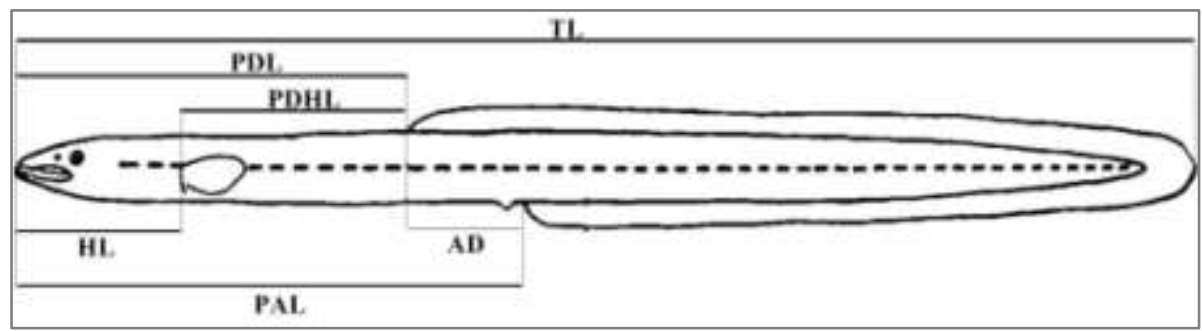

Sumber: Hakim et al. (2015)

Gambar 4 Pengukuran morfometrik ikan sidat, keterangan: total length (TL), head length (HL), predorsal head length (PDHL), pre-anal length (PAL), pre-dorsal length (PDL), dan ano-dorsal length

(AD) 


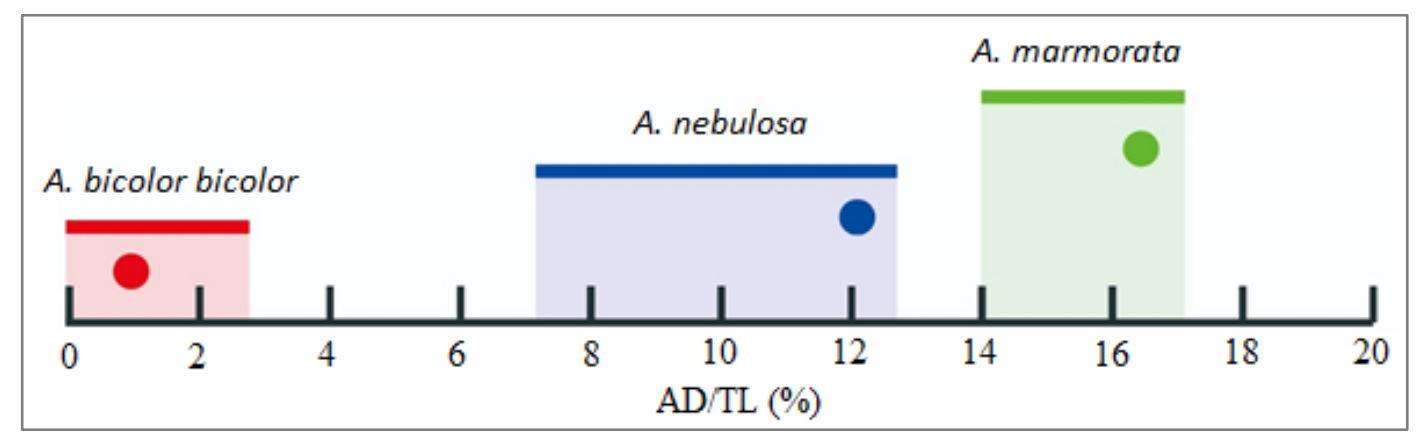

Gambar 5 Identifikasi morfologi glass eels berdasarkan persentase rasio ano-dorsal(AD) terhadap panjang total (TL)

\section{Analisis Keragaman Jenis}

Analisis keragaman hasil tangkapan bubu menggunakan persamaan indeks Shannon-Wiener (H'). Menurut Taurusman (2011) indeks keragaman hasil tangkapan dapat dievaluasi dengan dua pendekatan yakni berdasarkan jumlah bobot hasil tangkapan, dan jumlah spesies hasil tangkapan. Perhitungan H' digunakan untuk menentukan keragaman hasil tangkapan dari data hasil tangkapan bubu. Indeks keragaman dapat dihitung dengan rumus berikut (Krebs 2014):

$$
H^{\prime}=-\sum_{i=1}^{s} p i(\log 2) p i
$$

dengan:

$\mathrm{H}^{\prime} \quad$ = Indeks keragaman Shannon-Wiener;

$\mathrm{s} \quad=$ Jumlah total spesies ikan tangkapan;

$\mathrm{pi}=\mathrm{ni} / \mathrm{N}$;

ni = Jumlah individu spesies ke-i;

$\mathrm{N}=$ Jumlah total individu.

\section{HASIL DAN PEMBAHASAN}

\section{Identifikasi Hasil Tangkapan Sidat}

Ikan sidat memiliki nama lokal seperti ikan muling, ikan moa, ikan lubang, ikan larak dan ikan pelus. Menurut Berg (1949) dalam Deelder (1984), ciri ikan sidat memiliki tubuh memanjang dengan sirip dorsal, sirip caudal dan sirip anal bergabung menjadi satu, sirip dada ada dan sirip perut tidak ada dan tubuh diliputi sisik halus. Hasil identifikasi dari tiga jenis sidat yang tertangkap di perairan Terusan, Kabupaten Kaur selama penelitian, didapatkan Anguilla marmorata, Anguilla bicolor bicolor dan Anguilla nebullosa dengan hasil perbandingan nilai ano-dorsal seperti pada Tabel 1.

Tabel 1 Nilai pengukuran morfometrik hasil tangkapan sidat

\begin{tabular}{lcccc}
\hline \multicolumn{1}{c}{ Spesies } & $\begin{array}{c}\text { Panjang Total } \\
(\mathrm{TL})(\mathrm{cm})\end{array}$ & $\begin{array}{c}\text { Panjang Dorsal } \\
(\mathrm{LD})(\mathrm{cm})\end{array}$ & $\begin{array}{c}\text { Panjang Anal } \\
(\mathrm{LA})(\mathrm{cm})\end{array}$ & Ano-Dorsal (\%) \\
\hline A. bicolor bicolor & $31-37,4$ & $20,1-24,1$ & $18,9-22,8$ & $3,43-3,58$ \\
A. marmorata & $28,5-56$ & $18,1-38,2$ & $14,1-29,6$ & $13,7-18,81$ \\
A. nebullosa & $37,4-38$ & $25,1-26,1$ & $21,6-22,6$ & $9,21-9,36$ \\
\hline
\end{tabular}

Berdasarkan perhitungan didapat nilai perbandingan ano-dorsal/total length untuk spesies Anguilla bicolor bicolor adalah sebesar 3,43-3,58 \%, Anguilla marmorata memiliki nilai perbandingan 13,7-18,81 \% dan Anguilla nebulosa dengan nilai perbandingan 9,21-9,36\%. Hakim et al. (2015) melakukan pengelompokan spesies berdasarkan perbandingan ano-dorsall total length (AD/TL\%) di selatan Sukabumi hasilnya menunjukkan bahwa spesies $A$ bicolor bicolor $(4,58-8,85 \%), A$ marmorata 
(13,75-17,45 \%) dan A nebulosa (13,75-17,45 \%). Nilai yang diperoleh dari hasil analisa menunjukkan bahwa tiga jenis sidat memang berbeda spesies dilihat dari perbedaan hasil perhitungan ano-dorsall total length. Spesies Anguilla bicolor bicolor tercatat mendominasi hasil tangkapan di wilayah barat, dari Sumatera sampai pulau Jawa (Sugeha et al. 2008). Fahmi dan Hirnawati (2010) menyatakan terdapat tiga spesies sidat yakni Anguilla marmorata, Anguilla bicolor bicolor dan Anguilla nebullosa yang ditemukan pada sungai yang mengalir ke Samudera Hindia. Sebaran sidat yang menghuni perairan sungai provinsi Bengkulu terdapat tiga spesies yakni Anguilla marmorata, Anguilla bicolor bicolor dan Anguilla nebulosa (Fahmi 2015). Anguilla marmorata memiliki jumlah hasil tangkapan yang dominan yakni 17 ekor atau 70,83\% dari hasil tangkapan sidat. Jenis Anguilla bicolor bicolor hanya didapatkan 5 ekor atau 20,83\% dari hasil tangkapan. Jenis Anguilla nebullosa yang didapat sangat sedikit, hanya 8,33\% atau 2 ekor dari total hasil tangkapan sidat. Hal ini didukung penelitian oleh Sapto (2013) telah mengidentifikasi ada tiga jenis ikan sidat di Kabupaten Kaur, yaitu; A. bicolor bicolor, A. marmorata, dan A. nebulosa.

\section{Bobot sidat yang tertangkap dari setiap stasiun}

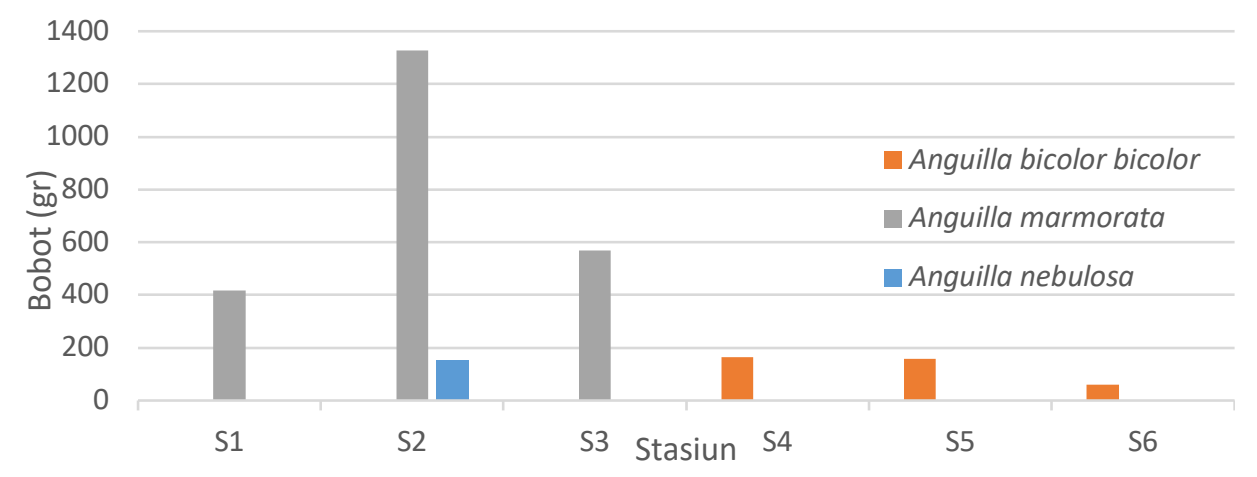

Gambar 6 Total bobot (gr) ikan sidat yang ditemukan pada setiap statsiun pengamatan

Berdasarkan hasil tangkapan sidat tersebar di setiap stasiun yang dijadikan titik pengambilan sampel. Hasil tangkapan sidat yang diperoleh paling tinggi ada pada stasiun dua dengan nilai bobot 1483,72 gram, sedangkan paling rendah ada pada stasiun enam dengan nilai bobot 59,8 gram. Hasil tangkapan sidat menunjukkan bahwa sidat jenis Anguilla marmorata dan Anguilla nebulosa terletak dibagian hulu sungai (stasiun 1 dan 2) dengan kondisi perairan dengan suhu rata-rata lebih rendah dan bersubstrat batuan, sedangkan Anguilla bicolor bicolor terletak di bagian hilir sungai (stasiun 4, 5 dan 6) dengan kondisi perairan payau dan bersubstrat lumpur berpasir. Pangerang et al. (2018), dalam penelitian yang dilakukan dibagian hulu sungai dengan substrat batuan menemukan spesies ikan sidat jenis Anguilla marmorata. Anguilla bicolor bicolor banyak ditemukan di perairan estuaria yang merupakan daerah yang rendah dengan elevasi 0-2 m dpl (Triyanto et al. 2019).

\section{Komposisi dan Keragaman Hasil Tangkapan}

Hasil tangkapan utama berupa sidat terdapat tiga spesies sedangkan hasil tangkapan bukan sidat (sampingan) dalam proses pengambilan sampel terdapat sembilan spesies ikan air tawar (Tabel 2). Hasil tangkapan dari perairan hulu dan hilir sungai menunjukan bahwa sidat merupakan hasil tangkapan yang paling dominan dengan persentase 56\% yakni jenis Anguilla marmorata sebesar 45,41\%, sedangkan hasil tangkapan sidat jenis Anguilla bicolor bicolor dan Anguilla nebulosa berturut-turut adalah $7,54 \%$ dan $3,04 \%$. Tangkapan sampingan dengan persentase total sebanyak $44 \%$ dengan rincian ikan glodok $0,14 \%$, ikan seluang $1,17 \%$, ikan balir 1,69\%, ikan betutu 1,89\%, udang galah 4,33\%, ikan gabus $5,13 \%$, udang galah $5,64 \%$, kepiting $11,91 \%$, dan ikan membehan dengan persentase yang paling tinggi untuk hasil tangkapan sampingan yakni 12,1\%. Sebaran sidat hasil tangkapan mendeskripsikan bahwa sidat jenis Anguilla marmorata dan Anguilla nebulosa terletak dibagian hulu sungai dengan kondisi perairan dengan suhu rata-rata lebih rendah dan bersubstrat batu-batuan, sedangkan Anguilla 
bicolor bicolor terletak di bagian hilir sungai dengan kondisi perairan payau dan bersubstrat lumpur berpasir. Sesuai dengan Pangerang et al. (2018), dalam penelitian yang dilakukan dibagian hulu sungai dengan substrat batuan menemukan spesies ikan sidat jenis Anguilla marmorata. Anguilla bicolor bicolor banyak ditemukan di perairan estuaria yang merupakan daerah yang rendah dengan elevasi 0$2 \mathrm{~m}$ dpl (Triyanto et al. 2019).

Tabel 2 Komposisi hasil tangkapan total bubu sidat

\begin{tabular}{|c|c|c|c|c|c|}
\hline $\begin{array}{l}\text { Jenis Hasil } \\
\text { Tangkapan }\end{array}$ & Nama Latin & Family & $\begin{array}{c}\text { Nama } \\
\text { Indonesia }\end{array}$ & Nama lokal & $\begin{array}{c}\text { Bobot } \\
\text { Total } \\
\text { (gram) }\end{array}$ \\
\hline Hasil & & & & & \\
\hline \multirow{3}{*}{$\begin{array}{c}\text { Tangkapan } \\
\text { utama }\end{array}$} & A. bicolor bicolor & Anguillidae & Sidat & Peluh rilau & 389,9 \\
\hline & A. marmorata & Anguillidae & Sidat & Pelus timah & 2311,31 \\
\hline & A. nebullosa & Anguillidae & Sidat & pelus & 154,6 \\
\hline \multirow{11}{*}{$\begin{array}{c}\text { Hasil } \\
\text { Tangkapan } \\
\text { Sampingan }\end{array}$} & & & & & \\
\hline & Scylla sp. & Portunidae & Kepiting & garak & 606,29 \\
\hline & & & & & \\
\hline & Rasbora sumatrana & Cyprinidae & - & Membehan & 615,99 \\
\hline & Rasbora dusonensis & Cyprinidae & - & Seluang & 59,8 \\
\hline & $\begin{array}{l}\text { Macrobrachium } \\
\text { rosenbergii }\end{array}$ & Palamonidae & $\begin{array}{l}\text { Udang } \\
\text { galah }\end{array}$ & $\begin{array}{l}\text { Hudang } \\
\text { buluran }\end{array}$ & 220,4 \\
\hline & Channa striata & Chanidae & Gabus & Ruan & 261 \\
\hline & Oxyeleotris marmorata & Eleotridae & Betutu & Balir & 85,9 \\
\hline & $\begin{array}{l}\text { Oxyeleotris } \\
\text { urophthalmoides }\end{array}$ & Eleotridae & Pelung & Pelung & 96 \\
\hline & $\begin{array}{l}\text { Boleophthalmus } \\
\text { boddarti }\end{array}$ & Oxudercidae & Glodok & Taiwai & 7,3 \\
\hline & Macrobrachium sp. & Palaemonidae & Udang & Udang & 286,9 \\
\hline
\end{tabular}

Ikan hasil tangkapan sampingan yang diperoleh dari alat tangkap bubu di Sungai Kaur umumnya didominasi oleh ikan-ikan dari famili Cyprinidae dan Portunidae. Famili Cyprinidae tersebar luas, dan umumnya berperan penting dalam menunjang kehidupan manusia. Menurut Karahan (2010) dalam Putri et al. (2014) Cyprinidae merupakan familia ikan air tawar yang terbesar, yang terdiri atas 220 genus dan 2.420 spesies. Ikan famili Cyprinidae merupakan ikan endemik Sumatera (Wargasasmita 2002). Distribusi kepiting (Scylla) ditemukan di wilayah estuari, dari penelitian Sulistiono et al. (2021), terdapat tiga jenis kepiting bakau yang tertangkap di sekitar lokasi Sungai Donan, Sagara Anakan yaitu Scylla tranquebarica, S. olivacea, dan $S$. Serrata. Hal inilah menunjukan peluang kemungkinan tertangkapnya kelompok ikan tersebut yang memang sangat tinggi pada alat tangkap bubu yang juga dioperasikan selama penelitian.

\section{Keragaman hasil tangkapan}

Hasil tangkapan bubu sidat di bagian hulu sungai memiliki keragaman jenis yang sedang. Jenis yang mendominasi berdasarkan hasil tangkapan menggunakan bubu sidat adalah kepiting (Scylla sp.) dan ikan membahan (Rasbora sumatrana) nilai keragaman berturut-turut 0,49 dan 0,46 sedangkan yang paling sedikit adalah Anguilla nebullosa dan ikan gabus (Channa striata) dengan nilai keragaman sama yakni 0,39. Gambar 9 menunjukan hasil tangkapan bubu sidat pada bagian hilir sungai dengan nilai keragaman yang relatif sedang. Hasil penelitian menunjukan bahwa udang (Macrobracium sp), memiliki nilai kegaraman yang paling tinggi yakni 0,44 sedangkan ikan glodok (Boleophthalmus boddarti) memiliki nilai keragaman paling rendah yakni 0,15. 


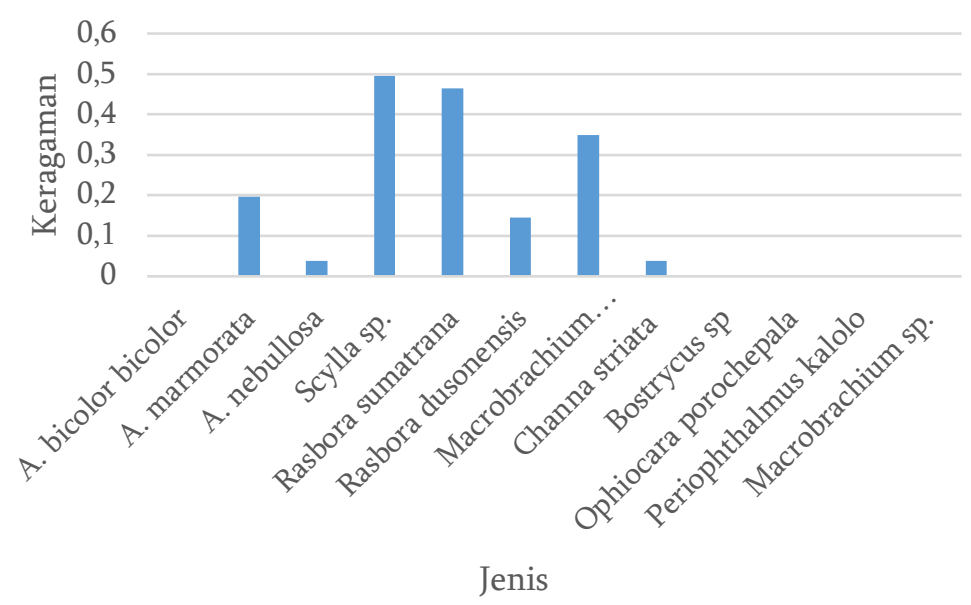

Gambar 7 Keragaman jenis ikan sidat dan biota lain di hulu sungai

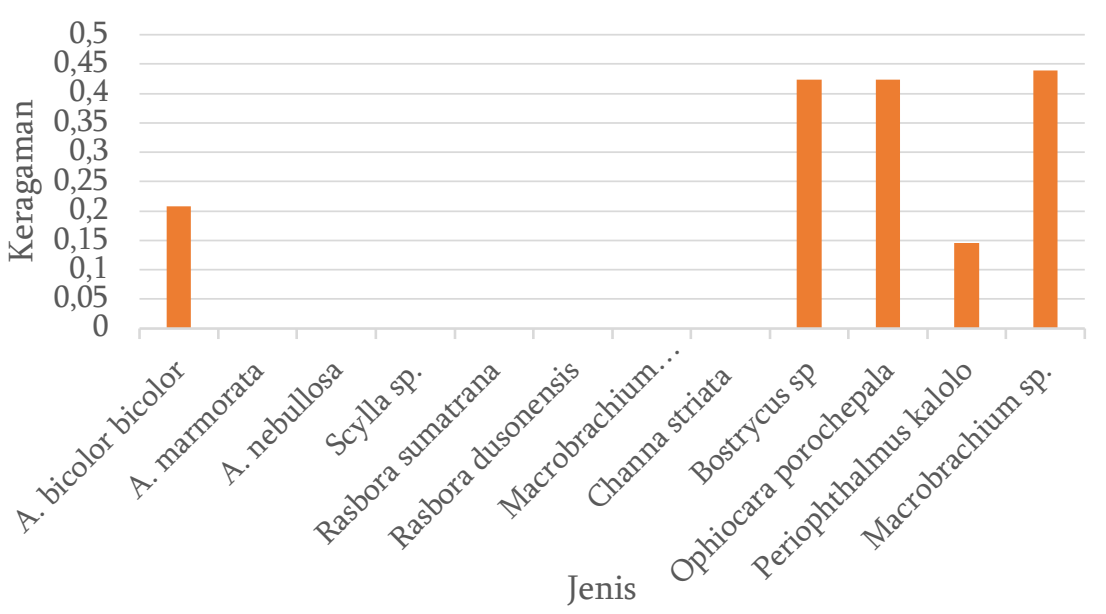

Gambar 8 Keragaman jenis ikan sidat dan biota lain di hilir sungai

\section{Indeks Shannon Wiener (H')}

Hasil perhitungan nilai indeks keragaman ikan hasil tangkapan secara spasial yakni untuk menggambarkan keragaman hasil tangkapan yang ada pada dua jenis perairan. Hasil tangkapan perairan hulu sungai dengan nilai indeks keragaman jenis $\left(\mathrm{H}^{\prime}\right)$ sebesar 1,73 . Hasil tangkapan perairan hilir sungai dengan nilai indeks keragaman jenis (H') sebesar 1,64. Keragaman hasil tangkapan antara dua jenis perairan mendapatkan nilai $\mathrm{H}^{\prime}$ yang sama yakni relatif sedang, namun secara spasial sebaran dari keragaman jenis ikan hasil tangkapan menggunakan bubu sidat perairan hulu memiliki nilai yang lebih tinggi. Indeks diversitas digunakan untuk melihat struktur keberagaman dari organisme pada lingkungan alamiahnya (Simanjuntak 2012). Namun demikian, indeks diversitas juga dapat digunakan untuk melakukan penilaian dari keberagaman hasil tangkapan yang diperoleh pada suatu alat tangkap (Nugroho et al. 2015). Semakin tinggi nilai indeks keragaman dari suatu alat tangkap, menunjukan bahwa alat tangkap tersebut memiliki tingkat selektivitas yang rendah (Nugroho et al. 2015). Konstruksi bubu yang digunakan tidak dibuat agar ikan-ikan yang tertangkap dapat keluar dari bubu, tanpa dilengkapi escapement gap (celah pelolosan) sehingga bubu memiliki selektivitas yang rendah. 


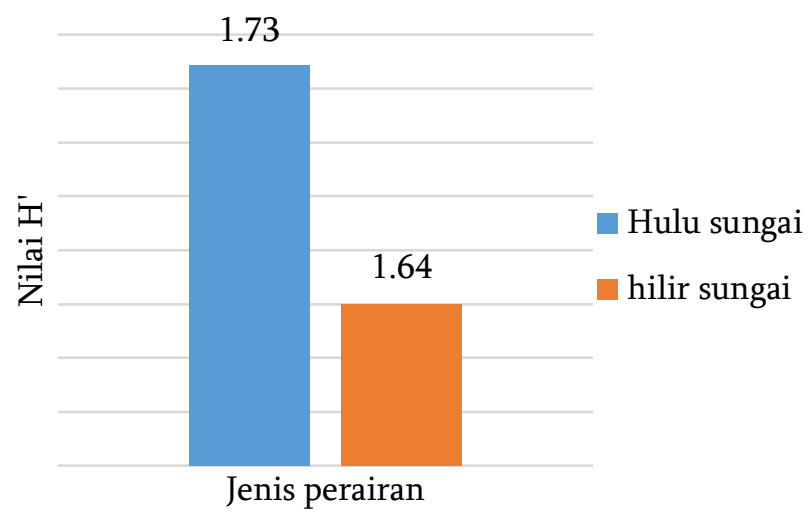

Gambar 9 Indeks keragaman jenis hasil tangkapan

Lebih jauh lagi Binur (2008) menyatakan keragaman jenis di bagian hulu sungai lebih tinggi dikarenakan kondisi lingkungan perairan yang relatif stabil, berbeda dengan bagian hilir sungai yang fluktuatif dengan masuk keluarnya air laut di perairan estuaria. Sementara itu Erika et al. (2018) menyatakan bahwa kondisi ekosistem perairan ditentukan dengan keanekaragaman spesies ikan yang hidup di ekosistem tersebut. Keanekaragaman di daerah estuaria tergolong lebih rendah dibandingkan dengan hulu sungai karena perairan bersifat terbuka dekat pantai. Sebagai bagian dari ekosistem estuari mempunyai peran ekologis penting antara lain: sebagai sumber zat hara dan bahan organik yang diangkut lewat sirkulasi pasang surut (tidal circulation), penyedia habitat bagi sejumlah spesies hewan yang bergantung pada estuaria sebagai tempat berlindung dan tempat mencari makanan (feeding ground) dan sebagai tempat untuk bereproduksi dan tempat tumbuh besar (nursery ground) terutama bagi sejumlah spesies ikan dan udang. Kawasan estuari juga merupakan wilayah migrasi bagi biota yang bersifat diadromous, baik anadroumus, katadromous dan amphidromous (Mc Dowal 2008).

Perairan hulu sungai dengan kondisi lingkungan yang relatif stabil merupakan habitat yang sesuai untuk habitat sidat. Ikan sidat dapat beradaptasi dengan suhu lingkungan $25^{\circ} \mathrm{C}$ hingga $28^{\circ} \mathrm{C}$ yang merupakan suhu optimal untuk laju pertumbuhan ikan sidat (Matsui 1982 dalam Herianti 2005). Hasil pengukuran $\mathrm{pH}$ pada setiap stasiun sebesar hulu sungai rata-rata 6,5 dan 6 pada hilir sungai. Nilai $\mathrm{pH}$ dapat mempengaruhi kondisi kimia perairan dan biotanya. Elver sidat mampu hidup pada kisaran $\mathrm{pH}$ sebesar 4 hingga 11, tetapi nilai $\mathrm{pH}$ terbaik pada kisaran 6,6 hingga 8,5 (Haryuni 2002). Secara keseluruhan terdapat perbedaan kondisi lingkungan antara hulu dan hilir sungai. Hasil pengukuran kondisi lingkungan diperairan Sungai Terusan Kabupaten Kaur seperti pada Tabel 2. Menurut Sandy et al. (2019) menyatakan kondisi ideal untuk keberlangsungan hidup ikan sidat berada pada suhu $27-29^{\circ} \mathrm{C}$ dan $\mathrm{pH}$ berkisar 6-9 sehingga kondisi lingkungan di Sungai Terusan masih dalam ambang yang sesuai untuk habitat sidat.

Tabel 3 Parameter fisika-kimia air sungai Terusan, Bengkulu

\begin{tabular}{lcccccc}
\hline \multirow{2}{*}{$\begin{array}{c}\text { Parameter fisika- } \\
\text { kimia }\end{array}$} & \multicolumn{7}{c}{ Stasiun } \\
\cline { 2 - 7 } & 1 & 2 & 3 & 4 & 5 & 6 \\
\hline Fisika & 6.1 & 82.8 & 73.9 & 169.9 & 189.1 & 122.3 \\
Kedalaman & 27.2 & 27 & 27.1 & 30.1 & 30.1 & 30.2 \\
Suhu & 34.1 & 37.4 & 30.6 & 55.1 & 68.2 & 44.8 \\
Kekeruhan & \multicolumn{7}{c}{ Hulury } \\
Kimia & 0 & 0 & 0 & 0.1 & 0.1 & 0.1 \\
Salinitas & 6.5 & 6.5 & 6.5 & 6 & 6 & 6 \\
pH & \multicolumn{7}{c}{ Batu besar dan kerikil } \\
Tipe substrat & \multicolumn{7}{c}{ Lumpur dan pasir } \\
\hline
\end{tabular}




\section{KESIMPULAN DAN SARAN}

Hasil tangkapan yang diperoleh terdiri tiga spesies sidat yaitu Anguilla bicolor bicolor yang merupakan jenis hasil tangkapan yang ditemukan pada bagian hilir sungai (estuari) dengan substrat pasir dan berlumpur. Sedangkan jenis Anguilla marmorata dan Anguilla nebulosa ditemukan di daerah yang bersubstrat batuan besar dan kerikil yakni perairan hulu sungai. Komposisi hasil tangkapan bubu sidat antara hulu sungai dan hilir sungai berbeda berdasarkan spesies hasil tangkapan. Secara keseluruhan komposisi hasil tangkapan didominasi oleh ikan sidat. Indeks keragaman hasil tangkapan pada perairain hulu dan hilir memiliki nilai H' masing-masing 1,7 dan 1,6.

Penelitian lanjutan perlu dilakukan untuk selama periode satu tahun untuk menganalisis perbedaan ukuran serta tingkat kematangan gonad yang tertangkap di sungai Terusan, Bengkulu.

\section{DAFTAR PUSTAKA}

Affandi R. 2005. Strategi pemanfaatan sumberdaya ikan sidat, Anguilla spp. di Indonesia. Jurnal Iktiologi Indonesia. 5(2): 77-81.

Arai T, Chino N, Zulkifli SZ, and Ismail A. 2011. Age Maturation of a Tropical Eel Anguilla bicolor bicolor in Peninsular Malaysia, Malaysia. Malays.Appl.Biol.40(1): 51-54.

Binur R. 2008. Keanekaragaman dan kelimpahan ikan di Danau Tes Bengkulu suatu upaya konservasi secara in-situ.Jurnal Natural. (5): 14-21.

Deelder, C.L. 1984. Synopsis of biological data on the eel Anguilla anguilla (Linneaus 1958). FAO, Rome: 1-59.

Dwijayanto A. 2018. Pemberdayaan komunitas muslim perbukitan melalui program sosial Bank Indonesia di Kaur Bengkulu. Jurnal Dakwah dan Sosial. 2(1): 155-167.

Erika R. Kurniawan. Umroh. 2018. Keanekaragaman ikan di perairan Sungai Linggang, Kabupaten Belitung Timur. Jurnal Sumberdaya Perairan. 12(2): 17-25.

Fahmi M. R. 2015. Konservasi genetika ikan sidat (Anguilla spp.) di Perairan Indonesia. Jurnal Penelitian Perikanan Indonesia. 21(1): 45-54.

Fahmi M. R., Hirnawati R. 2010. Keragaman ikan sidat tropis (Anguilla sp.) di perairan Sungai Cimandiri, Pelabuhan Ratu, Sukabumi. Prosiding Forum Inovasi Teknologi Akuakultur (pp. 18).

Hakim A. A., Kamal M. M., Butet N. A., Affandi R. 2015. Komposisi spesies ikan sidat (Anguilla spp.) di delapan sungai yang bermuara ke Teluk Palabuhan Ratu, Sukabumi, Indonesia. Jurnal Ilmu Dan Teknologi Kelautan Tropis. 7(2): 573-586.

Hartono D., Bakhtiar D., Ta Z. 2015. Distribution and collecting method of fingerling eel (Anguilla Sp.) in Bengkulu Province. In International Seminar on Promoting Local Resources for Food and Health, (pp. 12-13).

Haryuni. 2002. Migrasi elver sidat, Anguilla spp. memasuki muara Sungai Poso, Sulawesi Tengah [tesis]. Bogor (ID): Institut Pertanian Bogor.

Herianti I. 2005. Rekayasa lingkungan untuk memacu perkembangan ovarium ikan sidat. Oseanografi dan Limnologi Indonesia. 37: 25-41.

Krebs C. J. 2014. Ecological Methodology, 3rd edition. New York (USA): AddisonWesley Education Publishers.

Mc Dowal, R.M. 2008. Diadromus, history and ecology: a question scale. Hydrobiologia, 602: 5-14. 
Nugroho H. A., Rosyid A., Fitri A. D. P. 2015. Analisis indeks keanekaragaman, dominansi, dan proporsi hasil tangkapan non target pada jaring arad modifikasi di perairan Kabupaten Kendal. Journal of Fisheries Resources Utilization Management and Technology. 4(1): 1-11.

Pangerang U K, Sara L, Rianse U, Nur A I. 2018. Population Dynamics of The Eel (Anguilla marmorata) in Southeast Sulawesi Waters, Indonesia. AACL Bioflux. 11(2): 543-555.

Panjaitan R. L. K., Dede H., Maya A. F. U. 2018. Tipologi estuaria dan penggunaan alat tangkap bubu di muara Sungai Air manna Kabupaten Bengkulu Selatan. [Thesis]. Bengkulu (ID): Universitas Bengkulu.

Putri D. S. J., Abulias M. N., Bhawati D. 2014. Studi Kekerabatan Ikan Familia Cyprinidae yang Tertangkap di Sungai Serayu Kabupaten Banyumas. Scripta Biologica, Juni 2014. 1(2): 129-135.

Sandy N. K., Romadhoni W., Pamungkas T. P., Hayati A. N., Cheardi N. D. 2019. Sponcer (smart pond controller) pengendali lingkungan air kolam guna optimalisasi produksi ikan sidat di Budi Fish Farm, Ngaglik, Sleman, Daerah Istimewa Yogyakarta. Jurnal Edukasi Elektro. 3(1): 42-46.

Sapto M. 2013. Upaya pengelolaan habitat ikan sidat (Anguilla spp.) di Kabupaten Kaur Provinsi Bengkulu [disertasi]. Malang. Universitas Brawijaya.

Simanjuntak C. P. H. 2012. Keragaman dan struktur kumpulan ikan di anak sungai-anak sungai Sopokomil, Dairi, Sumatera Utara. Jurnal Iktiologi Indonesia. 12(2): 155-172.

Syahril S, Tantu F Y, Ndobe S. 2016. Distribusi spasial dan temporal ikan sidat (Anguilla sp.) yang bermigrasi ke hulu di Sungai Tinombo Kabupaten Parigi Mautong. Jurnal Sains dan Teknologi Tadulako. 5(2): 28-34.

Sugeha, H.Y., Sasanti, S.R., Wouthuyzen, S. and Sumadhiharga, O.K. 2008. Biodiversity, Distribution, and Abundance of the Tropical Angullid Eels in the Indonesian Waters. Marine Research in Indonesia, 33 (2): 129-138.

Sulistiono, Nurul M, Yahya dan Riani, E. 2021. Distribusi Scylla spp. di perairan estuari Sungai Donan Segara Anakan Bagian Timur, Cilacap. Habitus Aqua J, February 2021, 2(1): 1-11.

Taurusman A. A. 2011. Pengujian Indikator Ekologis Perikanan Berkelanjutan: Struktur Komonitas Hasil Tangkapan Ikan di Kabupaten Kotabaru, Kalimantan Selatan. Buletin PSP. 19(1): 1-12.

Triyanto, Affandi R, Kamal M. M., Haryani G. S. 2019. Fungsi Rawa Pesisir Sebagai Habitat Sidat Tropis Anguilla spp. di Estuaria Sungai Cimandiri, Sukabumi Jawa Barat. Jurnal Ilmu dan Teknologi Kelautan Tropis. 11(2): 475-492.

Tsukamoto K, Chow S, Otake T, Kurogi H, Mochioka N, Miller MJ, Aoyama J.2011.. Oceanic spawning ecology of freshwater eels in the western North Pacific. Nature Communications. 2(179): 1-9.

Wargasasmita S. 2002. Ikan Air Tawar Endemik Sumatera yang Terancam Punah. Jurnal Iktiologi Indonesia, 2(2): 41-49. 